\title{
Igrifikacijski elementi na mrežnim stranicama enciklopedija ${ }^{1}$
}

\author{
Josip Mihaljević \\ Institut za hrvatski jezik i jezikoslovlje, Zagreb \\ jmihalj@ihjj.hr
}

SAŽETAK: U radu se analiziraju igre i igrifikacijski elementi koji se nalaze na mrežnim stranicama enciklopedija. Analizirano je 92 mrežnih stranica općih i posebnih enciklopedija, od kojih 14 sadržava obrazovne mrežne igre ili određene igrifikacijske elemente. Te su igre razvrstane s obzirom na tip: kviz, križaljka, vješala, slagalica ili zagonetka, jedinstvene igre, igre povezivanja itd. Također su unutar igara enciklopedija te stranica enciklopedija identificirani igrifikacijski elementi koji su često prisutni: bodovanje, razine, priča, sustav nagrađivanja itd. Rezultati provedene analize pokazuju da još uvijek malo mrežnih enciklopedija sadržava igre i igrifikacijske elemente (15\%) te da od enciklopedija koje imaju igre većina ima kvizove (70\%), ali također da postoje neke jedinstvene obrazovne igre koje sadržavaju priču te mogu pomoći korisnicima u učenju geografije, činjenica o životinjama itd. Postoje i igre poput The Wikipedia Adventure, koje poučavaju korisnike kako se koristiti Wikipedijom. Istraživanje je provedeno u sklopu projekta Hrvatski mrežni rječnik - Mrežnik kako bi se osmislio konceptualni okvir igrifikacije mrežnoga rječnika. Metodologija izrade konceptualnoga okvira e-rječnika uz neke se preinake može iskoristiti i za izradu konceptualnoga okvira igrifikacije enciklopedije.

Ključne riječi: crowdsource enciklopedije; enciklopedije; igrifikacija; igrifikacijski elementi; kvizovi; mrežne stranice; obrazovne igre

\section{Uvod}

Igrifikacija (engl. gamification) proces je u kojemu se uzimaju elementi iz igara te ubacuju u svakodnevne procese kako bi ih se učinilo zabavnim i lakšim za izvođenje (Merriam-Webster 2019). Budući da se većina situacija može pretvoriti u igru, igrifikacija se može primijeniti u različitim područjima i aktivnostima ljudskoga života, poput obrazovanja (Kiryakova i dr. 2014), tjelovježbe i sporta (Shipherd i Burt 2018), prodaje (Boer 2013), ekonomije (Hamari i dr. 2015), menadžmenta (Sitzmann 2011), medicine (McCoy i dr. 2015: 22). Igrifikacija se može primjenjivati uporabom igrifika-

1 Ovaj je rad izrađen u okviru istraživačkoga projekta Hrvatski mrežni rječnik - Mrežnik (IP2016-06-2141), koji u cijelosti financira Hrvatska zaklada za znanost. 
cijskih elemenata u nesoftverskome okružju ili putem obrazovnih videoigara i programa (Kasurinen i Knutas 2018: 33). Ako se igrifikacija provodi s pomoću obrazovnih videoigara, riječ je o učenju utemeljenome na igri (engl. game based learning) (Yip 2007). Najčešći su elementi igrifikacije bodovanje i razine, ali su sve popularniji društveni igrfikacijski elementi koji uključuju sustav nagrađivanja, ljestvice poretka te kod aplikacija i igara virtualne avatare koji kao i u Role playing games (RPG igre - igre uloga) imaju stablo igračevih vještina (engl. skill tree) ${ }^{2}$ te trake koje prikazuju napredak igrača kroz sadržaje (Figueroa_Flores 2015: 39-40). Caponetto i drugi (2014: 50) analizirali su znanstvene radove o igrifikaciji u obrazovanju objavljene u razdoblju od 2000. do početka 2014. Analiza je pokazala da se nakon 2011. naglo povećao broj objavljenih radova: 206 radova objavljeno je 2011., dok je 1620 radova objavljeno 2013. Baza podataka Web of Science, koja bilježi istraživačke radove iz različitih znanstvenih časopis i baza podataka u prosincu 2020. ima pohranjeno 8658 radova koji sadržavaju ključnu riječ igrifikacija, od kojih ih je najviše bilo objavljeno u 2019. godini (1447), a najmanje ih je bilo objavljeno 2011. godine (3), kad se pojam igrifikacije tek počeo upotrebljavati.

Objavljeno je mnogo radova i istraživanja o igrifikaciji, ali se malo radova odnosi na igrifikaciju u području leksikografije ${ }^{3}$ te posebno povezanih s enciklopedijama. Primjerice Web of science trenutačno ima zabilježen samo jedan znanstveni rad koji sadržava ključne riječi igrifikacija i leksikografija ${ }^{4}$. Zato će se ovaj rad posebno usmjeriti na igrifikaciju koja je trenutačno prisutna na mrežnim stranicama enciklopedija. Analizirat će se mrežne stranice različitih enciklopedija te će se posebna pozornost usmjeriti na to koje enciklopedije sadržavaju bilo koji oblik igrifikacije i koji su igrifikacijski elementi prisutni u enciklopedijama. U zaključku rada prikazat će se konceptualni okvir igrifikacije enciklopedija koji je nastao prilagodbom konceptualnoga okvira izvorno izrađenoga za hrvatske mrežne rječnike ${ }^{5}$.

\section{Metodologija}

Na početku istraživanja trebalo je identificirati mrežne enciklopedije koje sadržavaju igre i igrifikacijske elemente. Mrežne stranice enciklopedija pronađene su s pomoću

2 Stablo igračevih vještina vizualna je reprezentacija različitih vještina po kategorijama koje igrač ima ili će ih tek imati ako napreduje u igri (Figueroa-Flores 2015: 39).

3 Više o igrifikaciji mrežnih rječnika te izradi konceptualnoga okvira igrifikacije hrvatskoga mrežnog rječnika vidi Mihaljević 2020a.

4 Naziv je rada Multilingual Lexicography with a Focus on Less-Resourced Languages: Data Mining, Expert Input, Crowdsourcing, and Gamification (Benjamin i Radetzky 2014).

5 Izrađen unutar doktorata Konceptualni okvir igrifikacije hrvatskoga mrežnoga rječnika (Mihaljević 2020b). 
akademskih tražilica $\operatorname{RefSeek}^{6}$ i iSEEK ${ }^{7}$ te je provjeren i popis enciklopedija sa stranice Wikipedije ${ }^{8}$. Prvo istraživanje provedeno je u rujnu 2019., ${ }^{9} \mathrm{kojim}$ je obuhvaćeno 70 enciklopedija i 181 mrežni rječnik. Od 70 pregledanih enciklopedija samo ih je 10 sadržavalo igre, što je manje od broja rječnika koji imaju 26 stranica s igrama. Istraživanje je prošireno u siječnju 2021. i tada su ponovno pregledane već analizirane enciklopedije kako bi se utvrdilo ima li promjena te su analizirane još 22 enciklopedije, pa je završna analiza obuhvatila 92 enciklopedije, od kojih ih 14 sadržava neki oblik igrifikacije. Nove su enciklopedije za koje je utvrđena igrifikacija Radiopaedia, ${ }^{10}$ How Stuff Works, ${ }^{11}$ Everipedia ${ }^{12}$ i Who $2^{13}$. Posljednje tri enciklopedije, kad su bile obuhvaćene prvom analizom, nisu bile igrificirane, ali sada sadržavaju igre. Analizom nisu obuhvaćene enciklopedije koje su izrađivali zaljubljenici (engl. fan) u igrice i filmove koristeći se wiki sustavima (npr. Wookieepedia ${ }^{14}$ je enciklopedija za franšizu Star Wars) jer ih ima previše. U tablici se bilježi koje enciklopedije sadržavaju bilo koji oblik igrifikacije (u prilogu 1 popis je svih analiziranih mrežnih stranica enciklopedija). Dalje su analizirane samo enciklopedije koje su igrificirane te je za svaku stranicu provjereno je li riječ o igrifikaciji usmjerenoj na korisnike koja se provodi s pomoću igara ili igrifikaciji koja je namijenjena urednicima kroz igrifikacijske elemente ugrađene u sustav uređivanja i stvaranja stranica enciklopedija. Za stranice koje sadržavaju igre utvrđeno je o kojemu tipu igre je riječ te koje igrifikacijske elemente sadržavaju igre. Također je za stranice na kojima je igrifikacija namijenjena urednicima utvrđeno koji se igrifikacijski elementi primjenjuju.

\section{Analiza e-enciklopedija}

Od 14 enciklopedija koje sadržavaju igrifikaciju ni jedna nije na hrvatskome jeziku. Neke enciklopedije nemaju svoju zasebnu stranicu, nego su integrirane u stranice drugih institucija, poput Talijanske enciklopedije znanosti, knjižernosti i umjetnosti, ${ }^{15}$

6 https://www.refseek.com/ (pristupljeno 13. XII. 2020.)

7 http://education.iseek.com/iseek/home.page (pristupljeno 13. XII. 2020.)

8 https://en.wikipedia.org/wiki/List_of_online_encyclopedias (pristupljeno 13. XII. 2020.)

9 O prvome provedenom istraživanju vidi i Mihaljević 2019.

10 https://radiopaedia.org/ (pristupljeno 19. I. 2021.)

11 https://www.howstuffworks.com/ (pristupljeno 21. I. 2021.)

12 https://everipedia.org/ (pristupljeno 19. I. 2021.)

13 https://www.who2.com (pristupljeno 19. I. 2021)

14 https://starwars.fandom.com/wiki/Main_Page (pristupljeno 19. I. 2021.)

15 http://www.treccani.it/enciclopedia/ (pristupljeno 16. XII. 2020.) 
koja se nalazi na stranici instituta Treccani, ili enciklopedije Baidu ${ }^{16}$ koja je integrirana na obavještajnome portalu Baike.com, pa je katkad bilo teško procijeniti koji su sadržaji leksikografski. Također neke enciklopedije, poput Winkler Prins, ${ }^{17}$ zahtijevaju registraciju prije pristupa te sadržavaju interaktivne sadržaje poput karata, animacija i videozapisa, ali ti sadržaji nisu igre i ne sadržavaju igrifikacijske elemente. Za pristup mrežnim stranicama enciklopedije World Book Encyclopedia potrebno je imati lozinku koja se dobiva kupnjom fizičke knjige, ali je iz videozapisa koji demonstrira stranicu ${ }^{18}$ vidljivo da se u dječjoj enciklopediji nalaze zagonetke, kvizovi i slagalice.

Za svaku enciklopediju utvrđeno je o kojemu je tipu enciklopedije riječ s obzirom na broj jezika te opseg obuhvaćenoga sadržaja. Od 14 enciklopedija s igrama deset su opće enciklopedije, a Encyclopedia Smithsonian ${ }^{19}$, Who2, Radiopredia i Medline Medical Encyclopedia ${ }^{20}$ posebne su enciklopedije od kojih su posljednje dvije medicinske. Od općih enciklopedija jedino se Wikipedija, Everipedia i Baidu Baike koriste crowdsourcingom za izradu sadržaja. Poveznice na igre koje se nalaze na Medline Medical Encyclopedia vanjske su poveznice na igre povezane s medicinskim nazivljem koje se nalazi na drugim stranicama. Igre za djecu izrađene na temelju enciklopedije Columbia Encyclopedia ne nalaze se na stranici rječnika, nego na stranici portala FactMonster ${ }^{21}$. Wikipedia je jedina višejezična enciklopedija koja sadržava igre, ali većina tih igara izrađena je za stranice napisane na engleskome. Igra Wikirace $e^{22}$ može se igrati i na stranicama enciklopedije napisanim na španjolskome, esperantu, francuskome, talijanskome, nizozemskome, poljskome, portugalskome i švedskome. Ostale su igre na jeziku na kojemu je enciklopedija napisana.

\footnotetext{
16 https://baike.baidu.com/ (pristupljeno 16. XII. 2020.)

17 http://www.winklerprins.com/ (pristupljeno 16. XII. 2020.)

18 https://www.youtube.com/watch?v=LhA4TLmQjQU (pristupljeno 21. XII. 2020.)

19 https://www.si.edu/explore (pristupljeno 16. XII. 2020.)

20 https://medlineplus.gov/encyclopedia.html (pristupljeno 16. XII. 2020.)

${ }^{21}$ https://www.factmonster.com/ (pristupljeno 16. XII. 2020.)

22 http://2pages.net/wikirace.php (pristupljeno 16. XII. 2019.)
} 
Studia lexicographica, 14(2020) 27, STR. 15-32

Josip Mihaljević: Igrifikacijski elementi na mrežnim stranicama enciklopedija

Tablica 1. Igrificirane enciklopedije po tipovima podjele i jezicima

\begin{tabular}{|c|c|c|}
\hline enciklopedija s igrama & vrsta enciklopedije & jezici pokriveni enciklopedijom \\
\hline Britannica & jednojezična, opća & engleski \\
\hline How Stuff Works & jednojezična, opća & engleski \\
\hline $\begin{array}{l}\text { Columbia Encyclopedia } \\
\text { (prikazna kroz FactMonster) }\end{array}$ & jednojezična, opća & engleski \\
\hline Encyclopedia Smithsonian & $\begin{array}{l}\text { jednojezična, posebna } \\
\text { (povijesnoumjetnička) }\end{array}$ & engleski \\
\hline Everipedia & $\begin{array}{l}\text { jednojezična, opća } \\
\text { (crowdsource) }\end{array}$ & engleski \\
\hline $\begin{array}{l}\text { Medline Medical Encyclope- } \\
\text { dia }\end{array}$ & $\begin{array}{l}\text { jednojezična, posebna } \\
\text { (medicinska) }\end{array}$ & engleski \\
\hline Radiopaedia & $\begin{array}{l}\text { jednojezična, posebna } \\
\text { (medicinska) }\end{array}$ & engleski \\
\hline Wikipedia & $\begin{array}{l}\text { višejezična, opća (crowd- } \\
\text { source) }\end{array}$ & postoje sadržaji napisani na 264 jezika \\
\hline Baidu Baike & $\begin{array}{l}\text { jednojezična, opća } \\
\text { (crowdsource) }\end{array}$ & kineski \\
\hline Krugosvet & jednojezična, opća & ruski \\
\hline Nationalencyklopedin & jednojezična, opća & švedski \\
\hline World Book Encyclopedia & jednojezična, opća & engleski \\
\hline Who2 & $\begin{array}{l}\text { jednojezična, posebna } \\
\text { (biografska) }\end{array}$ & engleski \\
\hline $\begin{array}{l}\text { Encyclopédie Larousse en } \\
\text { ligne }\end{array}$ & jednojezična, opća & francuski \\
\hline
\end{tabular}

Tablica 2. Broj enciklopedija po opsegu obuhvaćenoga sadržaja i broju jezika

\section{broj općih enciklopedija}

broj posebnih enciklopedia

4

10

povijesnoumjetnička

broj višejezičnih enciklopedija

broj jednojezičnih enciklopedija 


\subsection{Analiza igara na stranicama enciklopedija}

Od 14 enciklopedija koje sadržavaju igre samo 12 sadržava igre namijenjene posjetiteljima stranice. Druge dvije enciklopedije koriste se igrifikacijskim elementima kako bi vrednovali i nagradili aktivnosti urednika. $U$ drugoj je analizi utvrđeno da su tri enciklopedije u međuvremenu dodale igre na svoje stranice te da je Encyclopedia Britannica dodala križaljke koje nije imala u razdoblju kad je provedena prva analiza. Grand Larousse encyclopédique dodala je igre na svoju stranicu ${ }^{23}$, ali te igre nisu obrazovnoga karaktera nego je riječ o tipičnim kartaškim igrama te time ta enciklopedija nije zadovoljila kriterij da se uvrsti u ovu analizu. Također je u novoj analizi utvrđeno da je u enciklopediji Everipedia igrifikacija namijenjena urednicima stranica. Identificirani su ovi tipovi igara: kvizovi, vješala, igra povezivanja, križaljka, igra popunjavanja praznina, jedinstvene igre, slagalice te izvanmrežni materijali za igru.

Najčešći je tip igre, koji se nalazi u 10 enciklopedija, kviz znanja s ponuđenim odgovorima na pitanja. Razlog zašto je kviz najprisutniji tip igre vjerojatno je taj što ga je najlakše osmisliti i izraditi. Igra se temelji samo na pitanjima za koja igrač mora odabrati točan odgovor. Kod kviza uvijek je moguće izravno ispitati sve sadržaje te dati povratne informacije. $S$ tehničke je strane lako izraditi kviz jer se interakcija igrača temelji samo na tome da se pritisne određeni odgovor za koji program provjeri točnost na temelju točnoga odgovora pohranjenoga u kodu. Kvizove je zato lako programirati te također postoje mnoga gotova tehnološka rješenja za njihovu izradu (npr. Quizlet, Kahoot! i H5P). Kvizovi na stranicama enciklopedija osim teksta često sadržavaju i slike. Encyclopedia Britannica ističe se kvizovima ${ }^{24}$ jer ih ima podijeljene na temelju različitih kategorija, koji se temelje na sadržaju. Također se unutar tih kvizova registrirani korisnici mogu međusobno natjecati te s pomoću tipke na stranici izravno dijeliti kviz na društvenim mrežama. Slične kvizove ima i enciklopedija How Stuff Works, ali su njihovi kvizovi malo napredniji jer daju objašnjenje za točne ili pogrešne odgovore te uz svako pitanje nude i pomoć (engl. hint).

\footnotetext{
23 https://jeux.larousse.fr/ (pristupljeno 19. I. 2020.)

24 https://www.britannica.com/quiz/browse (pristupljeno 21. XII. 2020.)
} 


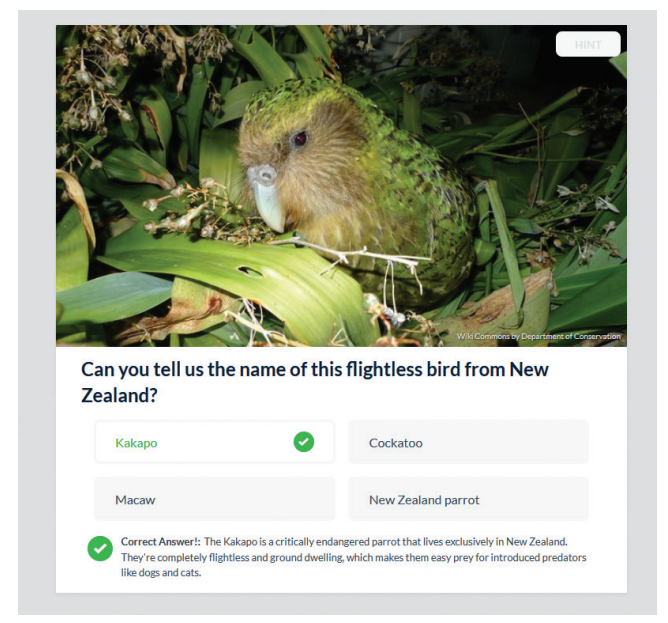

Slika 1. Primjer pitanja iz kviza sa stranice How Stuff Works koji ispituje prepoznavanje ptica

Jedinstvene igre drugi su najčešći tip obrazovne igre (4). Za razliku od igara na stranicama rječnika, enciklopedije katkad imaju jedinstvene obrazovne igre. Te jedinstvene igre imaju vlastiti način, pravila i radnju igre za razliku od tipičnih obrazovnih igara (npr. kvizova, križaljki). Jedan je od primjera takvih igara strateška igra Aquation: The Freshwater Access Game, ${ }^{25}$ u kojoj igrač mora u više različitih zemalja ravnomjerno izgraditi vodovodne cijevi kako bi svaka zemlja imala dovoljno vode u kućanstvu. Igrač pritom mora paziti na novac kojim se koristi za izgradnju cijevi, destilacijskih tvornica i istraživanja koja se odnose na uporabu vode te mora paziti na količinu vode koja se daje određenoj zemlji. Tom se igrom igrač upoznaje s važnošću raspodjele vode u svijetu te s potrebom upravljanja materijalnim resursima kako bi se ostvarili ciljevi potrebni za zadovoljavajući život. Enciklopedija Smithsonian također ima druge jedinstvene igre koje simuliraju određene situacije (npr. igra Disaster Detector ${ }^{26}$ uči igrače kako analizirati i interpretirati podatke povezane s prirodnim katastrofama kako bi mogli spriječiti sve buduće opasnosti poput poplava, uragana, vulkana itd.). Enciklopedia Who2, koja navodi biografije poznatih ljudi, ima igru pasijans, ${ }^{27} \mathrm{u}$ kojoj se na kartama nalaze poznati ljudi te se ispod njihove slike nalazi kratak tekst o njihovu najvećemu postignuću. Igre povezivanja, slagalice i zagonetke treći su tip igre (svaki od tih tipova igara nalazi se u tri enciklopedije). U igrama povezivanja treba spojiti dva pojma te su uglavnom rađene na principu do-

\footnotetext{
25 https://ssec.si.edu/aquation (pristupljeno 21. XII. 2020.)

26 https://ssec.si.edu/disaster-detector (pristupljeno 28. XII. 2020.)

27 https://solitaired.com/solitaire/space-flight (pristupljeno 19. I. 2021.)
} 
vlačenja (engl. drag-n-drop). Jedan je od primjera takve igre Habitats, ${ }^{28}$ igra u kojoj treba dovući odgovarajuću životinju na područje na kojemu najčešće živi. Slagalice uglavnom uključuju slike koje se moraju složiti, a zagonetke mogu biti raznolike te zadaju igraču problem koji mora riješiti razmišljanjem. Primjerice u igri za djecu Pilot Pals ${ }^{29}$ treba više različitih mehaničkih kotačića povezati kako bi avion radio. Križaljka se nalazi u dvije enciklopedije. Na stranici Medline Medical Encyclopedia nalazi se poveznica na križaljku koja se odnosi na spavanje ${ }^{30}$, a riječ je o slici koja se mora ispisati kako bi se riješila te time tu igru možemo svrstati u izvanmrežni materijal za igranje. Igre pamtilice, vješala i popunjavanja praznina prisutne su svaka samo u jednoj enciklopediji. Igra popunjavanja praznina u kojoj igrač treba unijeti odgovor u prazno polje u enciklopediji Medline Medical Encyclopedia služi za učenje brajice. ${ }^{31} \mathrm{U}$ istoj enciklopediji nalazi se poveznica za igru pamtilice ${ }^{32}$, koja radi tako da se spajanjem sličica dobiva informacija, šala ili savjet koji se odnosi na predmet sa slike. Igra vješala pokriva različite teme koje se nalaze u Columbia Encyclopedia ${ }^{33}$. Wikipedija jedina ima igre koje se odnose na uporabu te enciklopedije. Primjerice igra The Wikipedia Adventure ${ }^{34}$ kroz razine uči igrače kako da oblikuju svoje korisničke profile, uređuju stranice na Wikipediji, stavljaju citate za izvore koje objavljuju na mreži, provjere i procijene valjanost izmjena sadržaja stranica koje su izradili drugi korisnici. Drugi tip igre za Wikipediju igre su u kojima korisnik treba što brže s jedne stranice doći do druge s pomoću poveznica na stranicama. Primjeri su takvih igara Wikington Crescent, Wiki Ladders, Wikirace i The Wiki Game. ${ }^{35}$

Tablica 3. Tipovi igara koji se nalaze u e-enciklopedijama

\begin{tabular}{|c|l|l|l|l|l|l|c|c|}
\hline kviz & $\begin{array}{l}\text { jedin- } \\
\text { stvena } \\
\text { igra }\end{array}$ & $\begin{array}{l}\text { igra } \\
\text { poveziva- } \\
\text { nja }\end{array}$ & $\begin{array}{l}\text { slagalice } \\
\text { i } \\
\text { zago- } \\
\text { netke }\end{array}$ & $\begin{array}{l}\text { križalj- } \\
\text { ka }\end{array}$ & $\begin{array}{l}\text { igra } \\
\text { popunjava- } \\
\text { nja praznina }\end{array}$ & $\begin{array}{l}\text { izvanmrež- } \\
\text { ni } \\
\text { materijali } \\
\text { za igru }\end{array}$ & pamtilica & vješala \\
\hline 10 & 4 & 3 & 3 & 2 & 1 & 1 & 1 & 1 \\
\hline
\end{tabular}

\footnotetext{
${ }^{28}$ https://ssec.si.edu/habitats (pristupljeno 21. XII. 2020.)

29 https://giving.si.edu/mygiving/posting/pilot-pals (pristupljeno 21. XII. 2020.)

30 http://www.sleepforkids.org/html/clues.html (pristupljeno 21. XII. 2020.)

31 http://braillebug.org/Games.asp (pristupljeno 21. XII. 2020.)

32 https://www.fooddetectives.com/ (pristupljeno 21. XII. 2020.)

33 https://www.factmonster.com/games/hangman (pristupljeno 21. XII. 2020.)

34 https://en.wikipedia.org/wiki/Wikipedia:The_Wikipedia_Adventure (pristupljeno 23. XII. 2020.)

35 https://en.wikipedia.org/wiki/Wikipedia:Wikipedia_games (pristupljeno 23. XII. 2020.)
} 


\subsection{Analiza igrifikacijskih elemenata u enciklopedijama}

Nakon što je utvrđeno koje enciklopedije sadržavaju igre, analizirano je koji se igrifikacijski elementi primjenjuju u tim igrama te je li igrifikacija primijenjena na koji drugi način osim igara. Prepoznati su ovi igrifikacijski elementi: bodovanje, razine ili težine, vremensko ograničenje, značke ili drugi sustav nagrađivanja, napredak igrača, stablo igračevih vještina, priča, zadatci, ljestvice poretka te avatar igrača. Objašnjenje svakoga identificiranog igrifikacijskog elementa nalazi se u tablici 4.

Tablica 4. Objašnjenje osnovnih igrifikacijskih elemenata (Figueroa-Flores 2015: 39-40)

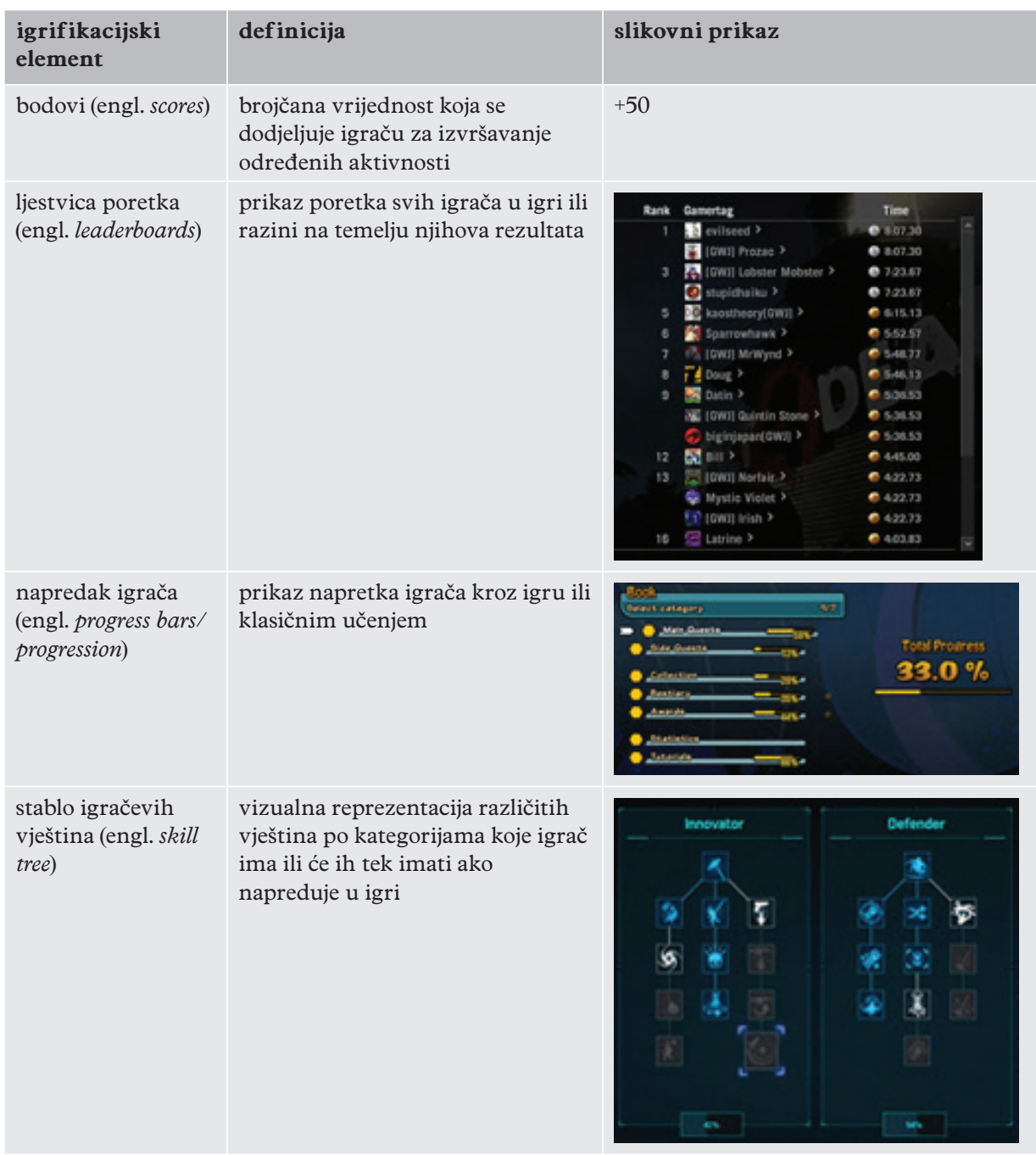


zadatci (engl. quests)

radnje koje igrač mora ostvariti kako bi dobio bodove i napredovao $\mathrm{u}$ igri

sadržajni ili težinski dijelovi igre

radnja igre otkriva se postupno dok korisnik prolazi kroz igru virtualna reprezentacija igrača s pomoću koje se bilježe bodovi i napredak u igri

mogući odnosi koje igrači mogu imati u igri (igranje u paru ili skupini, razmjena virtualnih dobara)

ograničenje koje je postavljeno igraču za izvršavanje određenoga zadatka
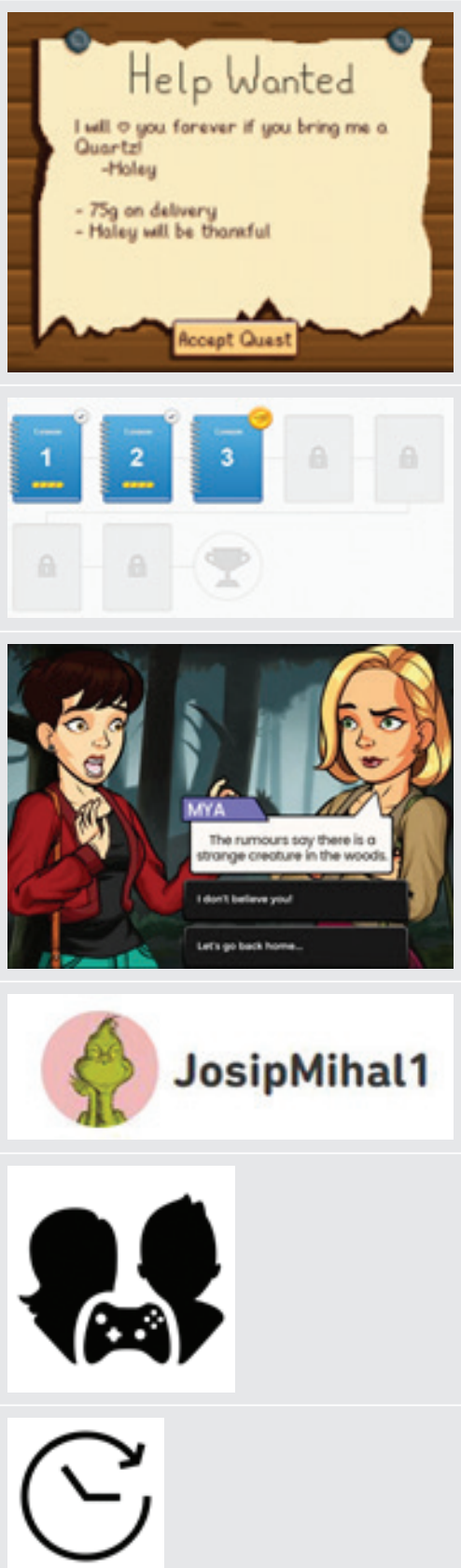


\begin{tabular}{l|l}
$\begin{array}{l}\text { sustav nagrađivanja } \\
\text { (engl. rewards }\end{array}$ & $\begin{array}{l}\text { unaprijed zadan sustav po kojemu } \\
\text { kystem) }\end{array}$ \\
$\begin{array}{l}\text { ostvarisnik dobiva nagrade kad } \\
\text { prođe određene razine ili postigne } \\
\text { određeni uspjeh u igri; primjenjuje } \\
\text { se kako bi se dodatno motiviralo } \\
\text { igrače }\end{array}$
\end{tabular}

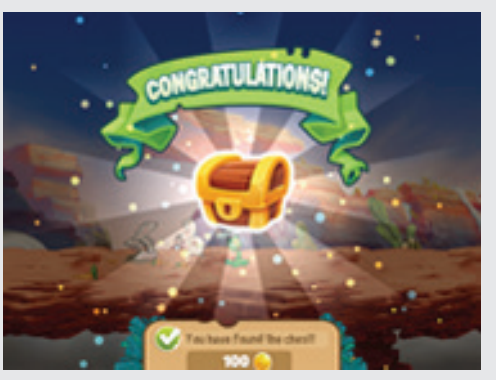

Najčešće prisutan igrifikacijski element jest bodovanje, koje je prisutno kod svih enciklopedija. Nakon toga slijedi podjela sadržaja igre na razine te vremensko ograničenje potrebno za rješavanje zadataka. Analizom je utvrđeno da se u enciklopedijama nalazi igrifikacijski element priče sa zadatcima, koji nije prisutan u rječnicima. Primjerice u igri iz enciklopedije Medline Medical Encyclopedia Food detectives ${ }^{36}$ igrač preuzima ulogu detektiva koji kroz različite manje igre (koje se zovu slučajevima) rješava zadatke koji su povezani s higijenom, zdravom prehranom i borbom protiv bakterija, koje su u priči prikazane kao glavni negativci. Igra Disaster Detector sadržava priču u kojoj se prate zemljopisne promjene i štiti grad od prirodnih katastrofa, potrebno je igraču dati razlog zbog kojega provodi određene aktivnosti, pa se to uglavnom radi s pomoću izmišljene radnje koja ima izmišljene likove. Kod identificiranih igrifikacijskih elemenata najčešće dolazi do njihova kombiniranja i miješanja. Primjerice element priče i zadataka povezan je u enciklopedijama Smithsonian i Medline Medical Encyclopedia, tj. u igri se zadatci izvršavaju kroz radnju igre. Također stablo igračevih vještina i traka koja pokazuje igračev napredak često su povezani u igrama i sustavima te se prikazuju unutar korisničkoga avatara. Ako enciklopedija primjenjuje avatare, to znači da često ima integrirane i društvene elemente jer korisnici s pomoću avatara mogu ostvariti interakciju s drugim igračima. Igra Wikipedia Adventure učinkovito se koristi igrifikacijskim elementima. Prvo se u igri izrađuje avatar pa se s virtualnim vodičem prolazi kroz sadržaj koji treba naučiti, a na kraju se korisniku postavljaju pitanja na koja on odabire odgovor. Za razine koje je prošao igrač osvaja značku te slično kao u RPG igrama postoji stablo igračevih vještina koje prikazuje igračev napredak u uređivanju stranica, razumijevanju prava korištenja te komunikaciji s drugim korisnicima. Društvene elemente može se uvrstiti is pomoću društvenih mreža, npr. korisnici kad završe kviz u Encyclopedia Britannica, mogu podijeliti sadržaj kviza i svoj rezultat na društvenim mrežama. Kvizovi su igre koje najčešće primjenjuju vremensko ograničenje za svako pitanje.

\footnotetext{
36 https://www.fooddetectives.com/ (pristupljeno 27. XII. 2020.)
} 
Enciklopedije Baidu Baike i Everipedia ne sadržavaju igre, ali zato primjenjuju igrifikacijske elemente unutar sučelja za urednike kako bi se podigla motivacija za rad. Svaki registrirani urednik u enciklopediji ima vlastiti avatar unutar kojega prikuplja bodove te mu se daju značke za njegove aktivnosti povezane s odgovorima na pitanja koja se postavljaju na stranici iz određenih područja, znanje korisnika boduje se i rangira u tablici unutar područja na koja odgovaraju. Također u enciklopediji Baidu Baike postoje tjedni zadatci koje korisnici mogu izvršavati kako bi osvojili više bodova.

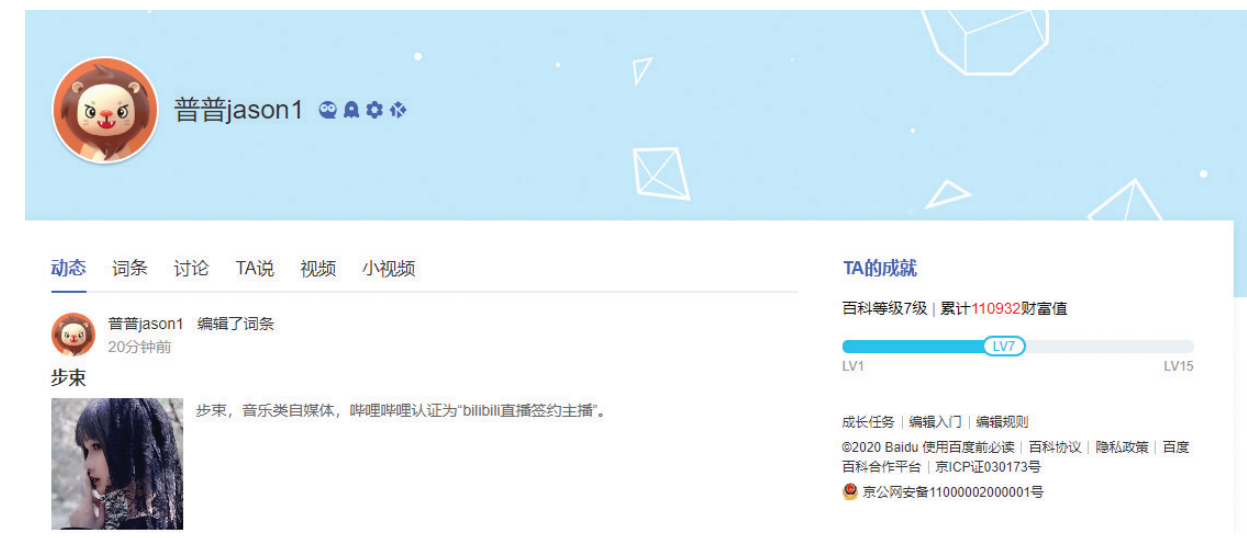

Slika 2. Prikaz avatara korisnika u enciklopediji Baidu Baike unutar kojega se vide aktivnosti i napredak korisnika

Tablica 5. Igrifikacijski elementi po enciklopedijama

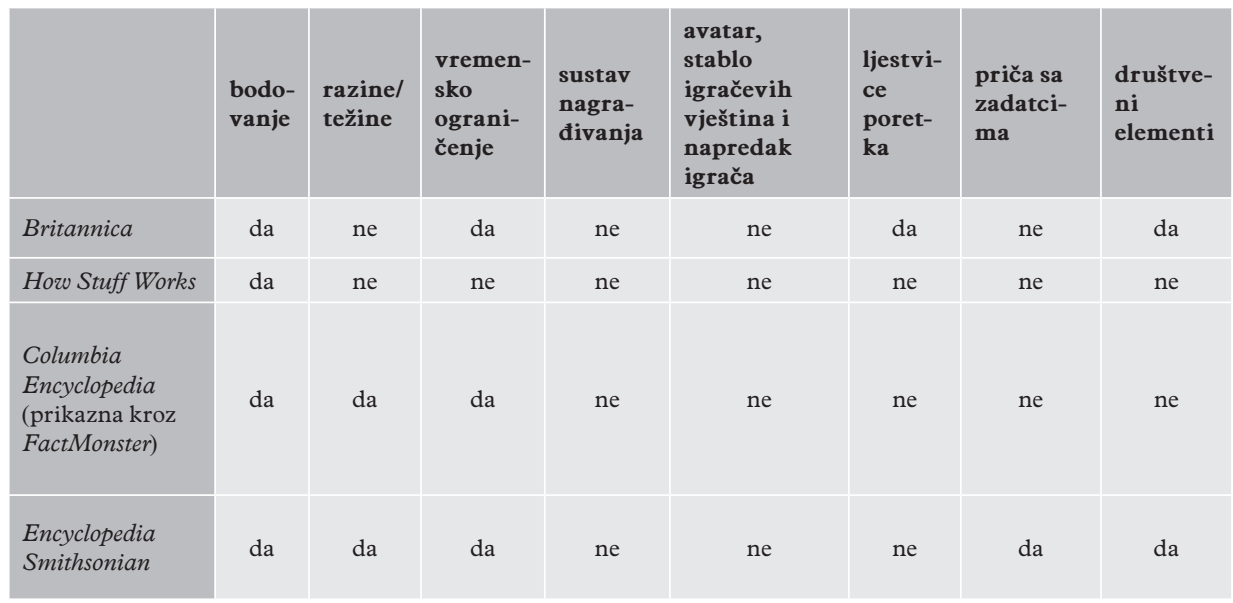




\begin{tabular}{|c|c|c|c|c|c|c|c|c|}
\hline Everipedia & $\mathrm{da}$ & ne & ne & da & da & $\mathrm{da}$ & ne & $\mathrm{da}$ \\
\hline $\begin{array}{l}\text { Medline Medical } \\
\text { Encyclopedia }\end{array}$ & $\mathrm{da}$ & $\mathrm{da}$ & $\mathrm{da}$ & ne & ne & ne & $\mathrm{da}$ & ne \\
\hline Radiopaedia & $\mathrm{da}$ & da & ne & ne & ne & ne & ne & ne \\
\hline Wikipedia & $\mathrm{da}$ & da & $\mathrm{da}$ & da & $\mathrm{da}$ & $\mathrm{da}$ & ne & da \\
\hline Baidu Baike & $\mathrm{da}$ & ne & ne & da & $\mathrm{da}$ & $\mathrm{da}$ & ne & $\mathrm{da}$ \\
\hline Krugosvet & $\mathrm{da}$ & ne & ne & ne & ne & ne & ne & ne \\
\hline $\begin{array}{l}\text { Nationalencyklo- } \\
\text { pedin }\end{array}$ & $\mathrm{da}$ & ne & ne & ne & ne & ne & ne & ne \\
\hline $\begin{array}{l}\text { Encyclopédie } \\
\text { Larousse en ligne }\end{array}$ & $\mathrm{da}$ & ne & ne & ne & ne & ne & ne & ne \\
\hline Who2 & $\mathrm{da}$ & ne & ne & ne & ne & ne & ne & ne \\
\hline $\begin{array}{l}\text { World Book } \\
\text { Encyclopedia }\end{array}$ & $\mathrm{da}$ & $\mathrm{da}$ & ne & ne & ne & ne & ne & ne \\
\hline
\end{tabular}

Tablica 6. Prikaz igrifikacijskih elemenata u enciklopedijama

\begin{tabular}{|l|l|l|l|l|l|l|l|}
\hline $\begin{array}{l}\text { bodova- } \\
\text { nje }\end{array}$ & $\begin{array}{l}\text { razi- } \\
\text { ne/ } \\
\text { težine }\end{array}$ & $\begin{array}{l}\text { vremen- } \\
\text { sko } \\
\text { ograniče- } \\
\text { nje }\end{array}$ & $\begin{array}{l}\text { susta- } \\
\text { vi } \\
\text { nagra- } \\
\text { diva- } \\
\text { nja }\end{array}$ & $\begin{array}{l}\text { avatar, } \\
\text { stablo } \\
\text { igračevih } \\
\text { vještina i } \\
\text { napredak } \\
\text { igrača }\end{array}$ & $\begin{array}{l}\text { ljestvi- } \\
\text { ce } \\
\text { poret- } \\
\text { ka }\end{array}$ & $\begin{array}{l}\text { priča sa } \\
\text { zadatci- } \\
\text { ma }\end{array}$ & $\begin{array}{l}\text { društveni } \\
\text { elementi }\end{array}$ \\
\hline 14 & 6 & 5 & 3 & 3 & 4 & 2 & 4 \\
\hline
\end{tabular}

\section{Zaključak}

Prva i druga analiza igrifikacijskih elemenata provedena je u razmaku od godinu i tri mjeseca. U tome kratkom razdoblju povećao se broj mrežnih enciklopedija i broj identificiranih enciklopedija koje primjenjuju igrifikaciju. To ukazuje na to da postupno dolazi do češće igrifikacije enciklopedijskih izdanja koja se sve češće prenose na mrežu ili izvorno stvaraju na mreži. U idućih nekoliko godina možemo očekivati povećanje primjene igara namijenjenih korisnicima te primjene igrifikacijskih elemenata za motivaciju uređivača stranica mrežnih enciklopedija.

Iz provedenih analiza može se vidjeti da su najčešće primijenjeni igrifikacijski elementi bodovanje (nalazi se u svim enciklopedijama s igrifikacijom) te podjela sadržaja na razine (6 od 14 enciklopedija s igrifikacijom). Bodovanje je vjerojatno naj- 
primjereniji igrifikacijski element jer se može lako primijeniti na svaku igru te je izrazito povezano s ostalim igrifikacijskim elementima kao što su ljestvice poretka igrača i sustavi nagrađivanja. Također je lako podijeliti dijelove igre na različite razine na temelju težine ili sadržaja. Vremensko ograničenje često se upotrebljava kod pitanja u kvizovima. Igrifikacijski elementi sustav nagrađivanja, avatar, stablo igračevih vještina i napredak igrača, priča sa zadatcima i ljestvice poretka nisu toliko česti u e-leksikografskim izdanjima, a u različitim istraživanjima i radovima često se ti elementi spominju kao elementi uspješne igrifikacije sadržaja jer mogu pobuditi zanimanje i podići motivaciju korisnika (Domínguez i dr. 2013; Rangaswami 2015; Qian i dr. 2016). Mogući je razlog slabije primjene tih igrifikacijskih elemenata u odnosu na bodovanje i podjele na razine to što ih je iz tehničkih razloga teže uvrstiti u igre jer je za avatar, ljestvice poretka i sustav nagrađivanja poželjno imati bazu podataka koja mora biti povezana s igrama. Baze podataka na internetu kojima igrač može uvijek pristupiti uglavnom se plaćaju mrežnim poslužiteljima. Avatar i sustavi nagrađivanja uglavnom se nalaze na istim leksikografskim stranicama (npr. Baidu Baike) jer su usko povezani (značke se često spremaju na avatare korisnika). Kvizovi su najčešći obrazovni tipovi igara zbog jednostavne primjene (u 10 od 14 enciklopedija s igrifikacijom). Enciklopedije također sadržavaju i druge tipove obrazovnih igara te postoje mnoge jedinstvene obrazovne igre koje se ne primjenjuju toliko često u obrazovanju (npr. Wikipedia Adventure za učenje uporabe Wikipedije, simulacije u enciklopediji Smithsonian). Ti jedinstveni tipovi igara često sadržavaju i igrifikacijski element priče koja sadržava različite zadatke. Igre kao što su križalike, igre povezivanja, kvizovi itd., koje imaju jednostavna pravila, najčešće ne zahtijevaju priču kako bi se igrale jer je cilj i način igranja igre jasan.

Unutar projekta Hrvatski mrežni rječnik - Mrežnik ${ }^{37}$ izrađen je model za igrifikaciju mrežnoga rječnika hrvatskoga jezika koristeći se obrazovnim igrama. Model se sastoji od sedam koraka koji se uglavnom izvršavaju ovim redoslijedom ${ }^{38}$ : određivanje obrazovnih sadržaja i ciljeva igara, osmišljavanje igara i određivanje koji će se igrifikacijski elementi uključiti, izrada igara, testiranje i dorada igara, objava igara, promocija igara i praćenje zadovoljstva korisnika. Tih sedam koraka igrifikacije mrežnoga rječnika polazna su točka pri promišljanju i izgradnji modela igrifikacije enciklopedija. Pri provedenoj analizi uočena je velika razlika u prvome koraku jer enciklopedije imaju drukčiju vrstu sadržaja od rječnika. Sadržaje opće enciklopedije vjerojatno se može lakše igrificirati od rječnika jer sadržavaju širi raspon znanja, tj. nisu ograničeni isključivo na riječi i rječničke definicije te se stoga može razviti više kreativnih igra.

37 Više o projektu: http://ihjj.hr/mreznik/page/o-mrezniku/1/ (pristupljeno 27. XII. 2020.)

38 Više o tome modelu vidi u radu »Igrifikacija Hrvatskoga mrežnog rječnika - Mrežnika« (Mihaljević 2020a) te doktorskome radu Konceptualni okvir igrifikacije hrvatskoga mrežnoga rječnika (Mihaljević 2020b). 


\section{PRILOG}

Popis mrežnih enciklopedija za koje je utvrđeno sadržavaju li igre i igrifikacijske elemente

Answers.com

Australian Dictionary of Biography

Baidu Baike

Ballotpedia

Banglapedia

Britannica

Citizendium

Columbia Encyclopedia (prikazna kroz FactMonster)

Computer Desktop Encyclopedia

Conservapedia

Croatian Biographical Lexicon

Den Store Danske Encyklopedi

Dictionary of Canadian Biography

Dictionary of Irish Architects

Digital Universe

Doctissimo

EcuRed

Emojipedia

Enciclonet

Enciclopedia Dantesca

Enciclopedia Italiana di scienze, lettere ed arti

Enciclopedia Libre Universal en Español

Encyclopedia Iranica

Encyclopaedia Metallum

Encyclopedia Universalis

Encyclopedia.com

Encyclopedia Astronautica

Encyclopedia Mythica

Encyclopedia of Alabama

Encyclopedia of China

Encyclopedia of Korean Culture

Encyclopedia of Life

Encyclopedia of Life Sciences

Encyclopedia of Life Support Systems

Encyclopedia of Philosophy
Encyclopedia of Symbols

Encyclopedia of Ukraine

Encyclopedia Sindhiana

Encyclopedia Smithsonian

Encyclopédie Larousse en ligne

Encyklopedia Internautica

Everipedia

Everything2

FishBase

Gazetteer for Scotland

Glottopedia

GNE

Grand Larousse encyclopédique

Gran Enciclopèdia Catalana

Great Medical Encyclopedia

Great Soviet Encyclopedia

Hamichlol

HistoryLink

How Stuff Works

Hrvatska enciklopedija

Internetowa encyklopedia PWN

Know Your Meme

Krugosvet

Le grand dictionnaire terminologique

Leksikon radija $i$ televizije

Marathi Vishwakosh

Marefa

MathWorld

Mawdoo3

Medline Medical Encyclopedia

Metapedia

MNopedia

Nationalencyklopedin

New World Encyclopedia

Open Site

Oxford Art Online 
Oxford Dictionary of National Biography

Proleksis enciklopedija

Radiopaedia

Rationalwiki

Reference.com

Sarvavijnanakosam

Scholarpedia

SIKART

Stanford Encyclopedia of Philosophy

Store norske leksikon

Superpedia

\author{
Tamil Encyclopedia \\ The Canadian Encyclopedia \\ The Catholic Encyclopedia \\ The Encyclopedia of New Zealand \\ The History of Nordic Women's Literature \\ The Literary Encyclopedia \\ Who2 \\ Wikipedia \\ Winkler Prins \\ World Book Encyclopedia
}

\section{LITERATURA}

Benjamin, Martin, Radetzky, Paula (2014). »Multilingual Lexicography with a Focus on Less-Resourced Languages: Data Mining, Expert Input, Crowdsourcing, and Gamification«. U: LREC 2014, Ninth International Conference on Language Resources and Evaluation. Reykjavik, European Language Resources Association.

Boer, Piet van den (2013). Introduction to Gamification. Hoboken: SG4Adults.

Caponetto, Ilaria, Earp, Jeffrey, Ott, Michela (2014). „Gamification and education: A literature review«. U: European Conference on Games Based Learning, 50-57. Brighton, Academic Conferences International Limited.

Domínguez, Adrián i dr. (2013). »Gamifying learning experiences: Practical implications and outcomes«. Computers E Education, 63, 386-392.

Figueroa-Flores, Jorge F. (2015). »Using Gamification to Enhance Second Language Learning«. Digital Education Review, 27 (21), 32-54.

Hamari, Juho, Huotari, Kai, Tolvanen, Juha (2015). »Gamification and economics«. U: Walz-The Gameful World. 139-161. Cambridge, MIT Press.

Kasurinen, Jussi, Knutas, Antti (2018). »Publication trends in gamification: A systematic mapping study«. Computer Science Review, 27, 33-44.

Kiryakova, Gabriela, Angelova, Nadezhda, Yordanova, Lina (2014). »Gamification in Education«. U: $9^{\text {th }}$ International Balkan Education and Science Conference. 679-683. Edirne, Trakya University.

McCoy, Lise, Lewis, Joy H., Dalton, David (2016). »Gamification and Multimedia for Medical Education: A Landscape Review«. The fournal of the American Osteopathic Association, 16 (1), 22-34.

Mihaljević, Josip (2019). »Gamification in E-Lexicography«. U: INFuture 2019: Knowledge in the Digital Age. 155-164. Zagreb, Department of Information and Communication Sciences, Faculty of Humanities and Social Sciences.

Mihaljević, Josip (2020a). »Igrifikacija Hrvatskoga mrežnog rječnika - Mrežnika«. Rasprave: Časopis Instituta za hrvatski jezik i jezikoslovlje, 46 (2), 407-434.

Mihaljević, Josip (2020b). »Konceptualni okvir igrifikacije hrvatskoga mrežnoga rječnika« (doktorska disertacija u rukopisu), Filozofski fakultet Sveučilišta u Zagrebu.

Qian, Meihua, Clark, Karen R. (2016). „Game-based Learning and 21st century skills: A review of recent research «. Computers in Human Behavior, 63, 50-58.

Rangaswami, JP. (2015). »When Peers Select Tasks and Teams«. The Gameful World: Approaches, Issues, Applications. 459-461. 
Shipherd, Amber M., Burt, Daniel J. (2018). »Game on! gamifying the sport psychology college classroom«. Fournal of Sport Psychology in Action, 9 (3), 147-158.

Sitzmann, Traci (2011). »A Meta-analytic Examination of the Instructional Effectiveness of Computer-Based Simulation Games«. Personnel Psychology, 64 (2), 489-528.

\section{MREŽNI IZVORI}

Academic Search Engine - RefSeek: https://www.refseek.com/ (pristupljeno 13. XII. 2020.)

Aquation: The Freshwater Access Game - Smithsonian Science Education Center: https://ssec.si.edu/ aquation (pristupljeno 21. XII. 2020.)

Baidu Baike: https://baike.baidu.com/ (pristupljeno 16. XII. 2020.)

Definition of Gamification - Merriam-Webster: https://www.merriam-webster.com/dictionary/gamificatio (pristupljeno 6. XII. 2020.)

Disaster Detector - Smithsonian Science Education Center: https://ssec.si.edu/disaster-detector (pristupljeno 15. II. 2020.).

Early Learning by World Book - YouTube: https://www.youtube.com/watch?v=LhA4TLmQjQU (pristupljeno 21. XII. 2020.).

Encyclopedia Britannica Quizzes - Britannica: https://www.britannica.com/quiz/browse (pristupljeno 21. XII. 2020.).

Encyclopedia Smithsonian - Smithsonian Institution: https://www.si.edu/explore (pristupljeno 16. XII. 2020.).

Encyclopédie Larousse en ligne - Jeux en ligne gratuits de Larousse: https://jeux.larousse.fr/ (pristupljeno 19. I. 2021.)

E-rječnici i e-leksikografija - Hrvatski mrežni rječnik: http:/ihjij.hr/mreznik/page/e-rjecnici-i-e-leksikografija/8/ (pristupljeno 21. I. 2020.)

Everipedia - The Wiki Encyclopedia for Everything: https://everipedia.org/ (pristupljeno 19. I. 2021.)

A Trusted Reference Site for Kids - Fact Monster: https://www.factmonster.com/ (pristupljeno 16. XII. 2020.)

Wookieepedia: The Star Wars Wiki - Fandom: https://starwars.fandom.com/wiki/Main_Page (pristupljeno 19. I. 2021.)

Games - braillebug: http://braillebug.org/Games.asp (pristupljeno 21. XII. 2020.)

Habitats - Smithsonian Science Education Center: https://ssec.si.edu/habitats. (pristupljeno 21. XII. 2020.)

Hangman - FactMonster: https://www.factmonster.com/games/hangman (pristupljeno 21. XII. 2020.)

Learn How Everything Works! - HowStuffWorks: https://www.howstuffworks.com/ (pristupljeno 21. I. 2021.)

Education - iSEEK: http://education.iseek.com/iseek/home.page (pristupljeno 13. XII. 2020.)

La cultura Italiana - Enciclopedia - Treccani: http://www.treccani.it/enciclopedia/ (pristupljeno 16. XII. 2020.)

List of online encyclopedias - Wikipedia: https:/en.wikipedia.org/wiki/List_of_online_encyclopedias (pristupljeno 13. XII. 2020.)

Medical Encyclopedia - MedlinePlus: https://medlineplus.gov/encyclopedia.html (pristupljeno 16. XII. 2020.) 
Pilot Pals - Smithsonian Science Education Center: https:/giving.si.edu/mygiving/posting/pilot-pals (pristupljeno 21. XII. 2020.)

Radiopedia - Radiopaedia.org, the wiki-based collaborative Radiology resource: https://radiopaedia.org/ (pristupljeno 19. I. 2021.)

Sleep for Kids - Teaching Kids the Importance of Sleep: http://www.sleepforkids.org/html/clues.html (pristupljeno 21. XII. 2020.)

Studie Winkler Prins - Winkler Prins: http://www.winklerprins.com/ (pristupljeno 16. XII. 2020.)

Food Detectives: https://www.fooddetectives.com/ (pristupljeno 27. XII. 2020.)

The Wikipedia Adventure. - Wikipedia: https:/en.wikipedia.org/wiki/Wikipedia:The_Wikipedia_Adventure (pristupljeno 23. XII. 2020.)

Who2. 2020. Biographies of famous people, celebrities, historic figures, and more: https://www.who2. com (pristupljeno 19. I. 2021)

Heros of Space and Flight Solitaire - Who2:: (https://solitaired.com/solitaire/space-flight (pristuplieno 19. I. 2021.)

Wikipedia games - Wikipedia: https://en.wikipedia.org/wiki/Wikipedia:Wikipedia_games (pristupljeno 23. XII. 2020.)

WikiRace: http://2pages.net/wikirace.php (pristupljeno 16. XII. 2020.)

Yip, Spencer - Siliconera: https:/www.siliconera.com/ubisoft-to-teach-ds-owners-french-and-spanish/ (pristupljeno 6. XII. 2020.).

\title{
GAMIFICATION ELEMENTS OF ONLINE ENCYCLOPEDIA WEBSITES
}

\author{
Josip Mihaljević \\ The Institute of Croatian Language and Linguistics, Zagreb \\ jmihalj@ihjj.hr
}

\begin{abstract}
The paper analyses games and gamification elements present on encyclopedia websites. The analysis included 92 websites of general and special encyclopedias, only 14 of which contain educational games or gamification elements. These games are categorised by type: quiz, crosswords, hangman, puzzles, drag and drop, unique games, etc. Gamification elements were also identified: scoring, levels, story, reward system, etc. The results of the analysis show that only a few encyclopedias contain games and gamification elements $(15 \%)$ and that quizzes are the game type which occurs most often on encyclopedia websites (ten encyclopedia websites). There are also unique educational games with a story that can help users in learning geography, facts about animals, etc. There are also games like The Wikipedia Adventure that help the users learn how to work with Wikipedia. The research was conducted within the project Croatian Web Dictionary - Mrežnik to create a conceptual framework for gamifying a web dictionary. The methodology of that conceptual framework can be used to create a conceptual framework for gamifying encyclopedias.
\end{abstract}

Keywords: crowdsource enyclopedias; educational games; encyclopedias; gamification; gamification elements; quizzes; websites

Članci su dostupni pod licencijom Creative Commons: Imenovanje-Nekomercijalno

(https://creativecommons.org/licenses/by-nc/4.0/). Sadržaj smijete umnožavati, distribuirati, priopćavati javnosti i prerađivati ga, uz obvezno navođenje autorstva, te ga koristiti samo u nekomercijalne svrhe. 